\title{
Allelopathy in the prymnesiophyte Chrysochromulina polylepis: effect of cell concentration, growth phase and $\mathrm{pH}$
}

\author{
Lisa Ejbye Schmidt, Per Juel Hansen* \\ Marine Biological Laboratory, University of Copenhagen, Strandpromenaden 5, 3000 Helsingør, Denmark
}

\begin{abstract}
Seven species (8 isolates) of dinoflagellates were exposed to a dense Chrysochromulina polylepis suspension. All species (with 1 exception) lost their motility, indicating that $C$. polylepis produces toxins, allelochemicals which affect other algae. The role of cell concentration, growth phase, and $\mathrm{pH}$ in the ability of C. polylepis to immobilize the dinoflagellate Heterocapsa triquetra was studied in batch cultures. Loss of motility of $H$. triquetra cells could be detected at cell concentrations of C. polylepis above $3 \times 10^{4}$ cells ml ${ }^{-1}$. Senescent cultures of C. polylepis did not immobilize H. triquetra cells. The ability of $C$. polylepis to immobilize $H$. triquetra cells was dependent on the $\mathrm{pH}$ of the growth medium. More non-motile $H$. triquetra cells were obtained in alkaline growth medium than in neutral or acidic media. Growth interactions between C. polylepis and 15 species (16 isolates) were also studied in mixed batch cultures using a nutrient replete growth medium. The algae selected for these experiments included diatoms, dinoflagellates, silicoflagellates, raphidophytes, euglenophytes, cryptophytes, and prasinophytes. C. polylepis had a harmful effect on all the tested algae, except the dinoflagellate Prorocentrum minimum. The harmful effect of $C$. polylepis was observed as an initial decrease in growth rate of the tested algae, followed by a decline in their population numbers. The harmful effect of $C$. polylepis on the tested algae could in a few cases be ascribed to the high $\mathrm{pH}$ in the culture medium. In most cases, however, the harmful effect was observed at a pH which did not affect the growth of these species when they were grown in monoculture. This indicates that toxins released by C. polylepis had a harmful effect on most of the tested algae in the mixed cultures.
\end{abstract}

KEY WORDS: Allelopathy $\cdot$ Toxicity $\cdot$ Growth phase $\cdot \mathrm{pH} \cdot$ Chrysochromulina polylepis

\section{INTRODUCTION}

Species of Chrysochromulina (Prymnesiophyceae) are ubiquitous in the world's ocean, where they usually are found in concentrations of 1 to 100 cells ml ${ }^{-1}$ (e.g. Thomsen et al. 1994). A bloom of Chrysochromulina polylepis in Scandinavian waters in 1988, causing extensive fish kills, was the first report of a toxic bloom of a Chrysochromulina species. At the peak of the bloom, cell concentrations of $C$. polylepis reached 5 to $10 \times 10^{4}$ cells ml $^{-1}$ (e.g. Edvardsen \& Paasche 1998).

*Corresponding author. E-mail: pjhansen@zi.ku.dk
Since then, a number of blooms of different Chrysochromulina species have been reported, some of which have caused fish mortality (reviewed by Edvardsen \& Paasche 1998). The bloom of C. polylepis in 1988 was almost monospecific at its peak occurrence and the abundance of zooplankton (copepods, heterotrophic protists) was very low (Nielsen et al. 1990). Field and laboratory experiments demonstrated that C. polylepis inhibited the activity of planktonic bacteria, heterotrophic protists, and copepods (Nielsen et al. 1990, Tobisen 1991).

Experiments were not carried out on the interaction between Chrysochromulina polylepis and co-occurring planktonic algae during the bloom. However, Cer- 
atium species found at the peak of the bloom were obviously moribund, since their cytoplasm had shrunk and pigmentation was lost (Dahl et al. 1989, Nielsen et al. 1990). These observations led to the hypothesis that C. polylepis may produce toxic substances that affect other algae (Dahl et al. 1989, Nielsen et al 1990, Maestrini \& Granéli 1991, Granéli et al. 1993). Myklestad et al. (1995) provided the first indications of allelopathy in C. polylepis. Addition of dense suspensions of C. polylepis to cultures of the diatom Skeletonema costatum resulted in growth inhibition of this alga. A similar effect was achieved using filtrates from dense C. polylepis cultures, indicating that toxic substances exuded from the algae to the medium caused the toxic effect. Some toxins, which interfere with cell membrane function, were extracted from C. polylepis cells during the bloom in 1988. The toxins were described as fatty acids (1-acyl-3-digalactosylglycerol and octadecapentenoic acid), but their chemical structures have not been fully elucidated (Yasumoto et al. 1990).

This paper investigates (1) the importance of cell concentration, growth phase and $\mathrm{pH}$ to the harmful effects of Chrysochromulina polylepis on the dino- flagellate Heterocapsa triquetra and (2) the possible harmful effect of $C$. polylepis on 16 isolates (15 species) of algae belonging to different phytoplankton taxa.

\section{MATERIALS AND METHODS}

Isolation and culture of algae. Information on isolation date, isolation place and clone designation of all the algae used in the present study is listed in Table 1. The Scandinavian Culture Collection of Algae and Protozoa, Botanical Institute, and the Marine Biological Laboratory, University of Copenhagen, Denmark, provided the algae. All algae were grown as non-axenic cultures in $f / 2$ medium (Guillard 1983) based on autoclaved seawater (salinity $30 \mathrm{PSU}$ ) at $15 \pm 1^{\circ} \mathrm{C}$ following a light: dark cycle of 16:8 h. Illumination was provided by cool white fluorescent lamps and cultures were kept at an irradiance of $25 \mu \mathrm{mol}$ photons $\mathrm{m}^{-2} \mathrm{~s}^{-1}$. Irradiance was measured using a Li-Cor ${ }^{\circledR}$, LI-1000 radiation sensor equipped with a spherical probe. The dimensions of all organisms were measured on live cells in the microscope ( $\mathrm{n}=20$ to 30 cells) and cell volumes estimated using simple volumetric formulae (Table 1).

Table 1. List of algae used in the experiments, their clone designation, isolation place and time, and the cell volume. $\mathrm{DK}=$ Denmark, $\mathrm{N}=$ Norway, $\mathrm{Au}=$ Australia

\begin{tabular}{|c|c|c|c|}
\hline Species & Clone & Isolation place and time & Cell volume $\left(\mu \mathrm{m}^{3}\right)$ \\
\hline \multicolumn{4}{|l|}{ Bacillariophyceae } \\
\hline Skeletonema costatum (Grev.) Cleve & K-0310 & Kattegat, DK 1989 & 200 \\
\hline \multicolumn{4}{|l|}{ Cryptophyceae } \\
\hline Rhodomonas marina (PA Dang.) Lemmerm. & K-0435 & Kattegat, DK 1990 & 570 \\
\hline \multicolumn{4}{|l|}{ Dictyochophyceae } \\
\hline Dictyocha speculum Ehrenb. & K-0301 & Kattegat, DK 1989 & 1800 \\
\hline \multicolumn{4}{|l|}{ Dinophyceae } \\
\hline Alexandrium ostenfeldii (Paulsen) Balech et Tangen & K-0287,K-0324 & Limfjorden, DK 1988 & 17000 \\
\hline Alexandrium tamarense (M. Lebour) Balech & K-0055 & Faroe Islands, DK & 17160 \\
\hline Ceratium furca (Ehrenberg) Claparede et Lachmann ${ }^{a}$ & & Øresund, DK 1995 & 35000 \\
\hline Ceratium lineatum (Ehrenberg) Cleve ${ }^{\mathrm{a}}$ & & Øresund, DK 1995 & 8100 \\
\hline Ceratium tripos (OF Muller) Nitsch ${ }^{\mathrm{a}}$ & & Øresund, DK 1995 & 110000 \\
\hline Gymnodinium mikimotoi Adachi et Fukuyo & K-0260 & Oslofjorden, N 1977 & 5200 \\
\hline Heterocapsa triquetra Ehrenb. & K-0481 & Øresund, DK 1988 & 2050 \\
\hline Prorocentrum micans Ehrenb. & K-0335 & Kattegat, DK 1989 & 10000 \\
\hline Prorocentrum minimum (Pavill.) J. Schiller & K-0295 & Kattegat, DK 1989 & 1040 \\
\hline \multicolumn{4}{|l|}{ Prymnesiophyceae } \\
\hline Chrysochromulina polylepis Manton \& Parke & K-0259 & Øresund, DK 1988 & 140 \\
\hline Chrysochromulina simplex Estep et al. & $\mathrm{K}-0272$ & Victoria, Au 1988 & 34 \\
\hline \multicolumn{4}{|l|}{ Euglenophyceae } \\
\hline Eutreptiella gymnastica Throndsen & K-0333 & Kattegat, DK 1988 & 850 \\
\hline \multicolumn{4}{|l|}{ Prasinophyceae } \\
\hline Pyramimonas propulsa Moestrup et DRA Hill & K-0005 & Port Phillip Bay, Au? & 1800 \\
\hline \multicolumn{4}{|l|}{ Raphidophyceae } \\
\hline Heterosigma akashiwo (Hada) Hada & K-0246 & Unknown locality & 1900 \\
\hline
\end{tabular}


Experimental conditions. All experiments were carried out at an irradiance of $60 \mu \mathrm{mol}$ photons $\mathrm{m}^{-2} \mathrm{~s}^{-1}$. The algae were adapted to this irradiance for at least $14 \mathrm{~d}$ prior to each experiment. Only cells from exponentially growing cultures were used for inoculation. For enumeration of cells, subsamples $(2 \mathrm{ml})$ were fixed in acidic Lugol's iodine (2.5\% final concentration). Cells were counted in a Sedgewick-Rafter ${ }^{\circledR}$ chamber or a multidish well (Nunclon ${ }^{\circledR}$ ). Each count was based on at least 400 cells. Growth rates were measured as increase in cell numbers and were calculated assuming exponential growth:

$$
\mu\left(\mathrm{d}^{-1}\right)=\frac{\left(\ln N_{1}-\ln N_{0}\right)}{t}
$$

where $N_{0}$ and $N_{1}$ are number of cells at time $t_{0}$ and $t_{1}$, and $t$ is the difference in time between samples. A minimum of 3 sampling points was included in the calculation. All experiments were carried out in triplicates. $\mathrm{pH}$ was measured using a Sentron ${ }^{\circledR} \mathrm{pH}$-meter (model 2001).

Effect of Chrysochromulina polylepis on the motility of Heterocapsa triquetra. Initial experiments had shown that $H$. triquetra which had been exposed to a dense culture of $C$. polylepis became non-motile. In order to quantitatively study the change in swimming behaviour, the following experiment was carried out: $0.25 \mathrm{ml} \mathrm{H}$. triquetra culture (ca 500 cells) was mixed with $2 \mathrm{ml}$ toxic culture of C. polylepis $\left(1.5 \times 10^{5}\right.$ cells $\mathrm{ml}^{-1}$ ) in a multidish well. The number of cells lying nonmotile at the bottom was enumerated after 10, 20, 30, $40,50,90,120$, and 150 min using an inverted microscope. A control experiment was carried out in a similar way using $\mathrm{f} / 2$ medium instead of the $C$. polylepis culture. The experiments were carried out in triplicates.

Based on the results from these experiments, the following experimental design was used in all subsequent experiments dealing with the effect of Chrysochromulina polylepis on the motility of Heterocapsa triquetra (unless otherwise stated): a C. polylepis culture $(2 \mathrm{ml})$ was mixed with a $H$. triquetra culture $(0.25 \mathrm{ml}$ ca 500 cells) in a multidish well. The cultures of $H$. triquetra used in these experiments were kept in exponential growth at a concentration of $1 \times 10^{4} \mathrm{cells} \mathrm{ml}^{-1}$. Prior to experiments, a part of the $H$. triquetra culture was diluted to attain a concentration of ca 2000 cells ml-1 After $2 \mathrm{~h}$ of exposure to C. polylepis, the number of nonmotile $H$. triquetra cells lying at the bottom of the well was enumerated. Subsequently, Lugol's $(50 \mu l)$ was added to each well and the total number of $H$. triquetra cells in the well was enumerated after the cells had settled. This made it possible to calculate the percentage of cells which were affected by $C$. polylepis during the incubation. A control experiment was carried out using $\mathrm{f} / 2$ medium instead of the C. polylepis culture.
Effect of Chrysochromulina polylepis on the motility of 8 isolates $(7$ species) of dinoflagellates. The dinoflagellates were grown in Nunclon ${ }^{\oplus}$ tissue culture flasks $(60 \mathrm{ml})$, which were mounted on a plankton wheel in order to keep the algae in suspension. A culture of C. polylepis was inoculated in a 11 Pyrex $^{\circledR}$ bottle containing $400 \mathrm{ml}$ and allowed to grow to a cell density of $1.9 \times 10^{5}$ cells ml ${ }^{-1}$. At this concentration, $2 \mathrm{ml}$ of the C. polylepis culture were transferred to a multidish and mixed with $0.25 \mathrm{ml}$ of the dinoflagellate culture. The number of non-motile dinoflagellates was enumerated after $2 \mathrm{~h}$ of exposure to the C. polylepis culture. Otherwise the experiment was carried out using the experimental design described in the section 'Effect of Chrysochromulina polylepis on the motility of Heterocapsa triquetra'.

Ability of Chrysochromulina polylepis culture to immobilize Heterocapsa triquetra cells: dependence of cell concentration and growth phase. C. polylepis was inoculated in a 11 Pyrex $^{\circledR}$ bottle containing $400 \mathrm{ml}$ growth medium and allowed to grow. Daily $\mathrm{pH}$ and cell concentrations were measured and the culture was tested for its ability to immobilize $H$. triquetra cells. A control experiment was carried out with Chrysochromulina simplex, instead of C. polylepis, to study the effect of a non-toxic Chrysochromulina species on the motility of $H$. triquetra.

Immobilization of Heterocapsa triquetra cells by Chrysochromulina polylepis: the effect of pH. Chrysochromulina polylepis and $H$. triquetra were grown separately in 11 Pyrex $^{\circledR}$ bottles containing $400 \mathrm{ml}$ growth medium. Three cultures of C. polylepis were inoculated and allowed to grow to different cell concentrations $\left(1.8 \times 10^{4}, 4.3 \times 10^{4}\right.$, and $\left.1.5 \times 10^{5} \mathrm{cells} \mathrm{ml}^{-1}\right)$. From each culture, 8 times $40 \mathrm{ml}$ of the C. polylepis culture were transferred to small $60 \mathrm{ml}$ tissue culture flasks and $\mathrm{pH}$ was altered by addition of $0.2 \mathrm{M} \mathrm{HCl}$ or $\mathrm{NaOH}$, except for 1 flask in which the original $\mathrm{pH}$ was maintained. $H$. triquetra cells were added to each flask $\left(0.9 \mathrm{ml}\right.$ containing $1 \times 10^{4}$ cells $\left.\mathrm{ml}^{-1}\right)$ and $\mathrm{pH}$ was measured. Each mixture $(2.25 \mathrm{ml})$ was added to a multidish well, and the number of non-motile $H$. triquetra cells was counted after $2 \mathrm{~h}$. A similar experiment was carried out using $f / 2$ growth medium, instead of the C. polylepis culture, in order to study the effect of $\mathrm{pH}$ itself on the motility of $H$. triquetra.

Interactions between Chrysochromulina polylepis and Heterocapsa triquetra in mixed batch cultures. All these experiments were carried out in Nunclon ${ }^{\circledR}$ tissue culture flasks $(260 \mathrm{ml})$, which were mounted on a plankton wheel (1 rpm) in order to keep the algae in suspension.

In the first set of experiments, the growth responses of Chrysochromulina polylepis and Heterocapsa triquetra in monocultures and in mixed cultures were 
studied. The cultures were inoculated and allowed to grow. Daily pH and cell concentrations were measured and the cultures containing $C$. polylepis were tested for their ability to immobilize $H$. triquetra cells. In the case of the mixed culture, the number of $H$. triquetra cells (both motile and non-motile) already in the culture was also measured. Control experiments (on both growth and motility) were carried out with Chrysochromulina simplex, instead of C. polylepis, to study the effect of a non-toxic Chrysochromulina species on H. triquetra.

In the second set of experiments, the importance of the initial Chrysochromulina polylepis concentration for the growth interaction between $C$. polylepis and Heterocapsa triquetra in mixed cultures was studied. Three different initial concentrations of $C$. polylepis were used $\left(2 \times 10^{3}, 5 \times 10^{3}\right.$ and $1 \times 10^{4}$ cells ml $\left.{ }^{-1}\right)$, while the initial concentration of $H$. triquetra was the same in all experiments $\left(10\right.$ cells $\left.\mathrm{ml}^{-1}\right)$. The cultures were inoculated and allowed to grow. $\mathrm{pH}$ and cell concentrations were measured daily.

Growth interactions between Chrysochromulina polylepis and algae belonging to different taxa. Growth interactions between C. polylepis and 15 isolates of algae (14 species) were carried out in 2 sets of growth experiments. In the first set of experiments, C. polylepis was grown in mixed cultures with 1 representative of the following algal classes: cryptophytes, diatoms, dictyophytes, dinoflagellates, euglenophytes, prasinophytes, and raphidophytes. In the second set of experiments, $C$. polylepis was grown in mixtures with 9 isolates (8 species) of dinoflagellates. $H$. triquetra was used in both sets of experiments to test the reproducibility of the experimental setup. Growth experiments were carried out in $260 \mathrm{ml}$ tissue culture flasks, which were mounted on a plankton wheel (1 rpm) in order to keep the algae in suspension. Initial concentrations of the tested algae in these experiments were from 20 to 100 cells ml ${ }^{-1}$, while the initial concentration of C. polylepis was 2000 cells $\mathrm{ml}^{-1}$. The growth of the selected algae in monocultures was studied for comparison.

\section{RESULTS}

\section{Effect of Chrysochromulina polylepis on the motility of Heterocapsa triquetra and other dinoflagellates}

The dinoflagellate Heterocapsa triquetra lost its ability to swim when added to a suspension of Chrysochromulina polylepis containing $1.5 \times 10^{5} \mathrm{cells} \mathrm{ml}^{-1}$ (Fig. 1). After $H$. triquetra had been exposed to the suspension for $10 \mathrm{~min}$, ca $25 \%$ of the $H$. triquetra cells were found non-motile at the bottom of a multidish well. After an exposure time of $50 \mathrm{~min}$, all $H$. triquetra cells could be found non-motile at the bottom. Non-motile cells were not found in the control experiment using f/2 medium instead of the C. polylepis culture (Fig. 1).

Eight isolates of dinoflagellates were exposed to a Chrysochromulina polylepis suspension containing $1.9 \times$ $10^{5}$ cells ml ${ }^{-1}$ (Fig. 2). The percentage of cells which became non-motile after $2 \mathrm{~h}$ of exposure to the dense $C$. polylepis culture varied considerably among species (Fig. 2A,B). The motility of all species, except Gymnodinium mikimotoi, was affected by C. polylepis. Heterocapsa triquetra was the most affected species. After $2 \mathrm{~h}$ of exposure to the $C$. polylepis culture, $94 \%$ of the $H$. triquetra population had become non-motile. No difference in behavioural response was observed between the 2 different isolates of Alexandrium ostenfeldii, when they were exposed to the C. polylepis culture (Fig. 2A).

A significant negative relationship was found between the percentage of the dinoflagellates that became non-motile after $2 \mathrm{~h}$ of exposure to Chrysochromulina polylepis and their cell volume $(\mathrm{p}=0.0064$, $\mathrm{R}^{2}=0.74$ ), if Gymnodinium mikimotoi (which was not affected) was left out (Fig. 2C, Table 2).

\section{Effect of Chrysochromulina polylepis on the motility of Heterocapsa triquetra: dependence of cell concentration and growth phase}

A batch culture of Chrysochromulina polylepis culture was initiated and allowed to grow. Daily, subsamples of the culture were tested for their ability to immobilize Heterocapsa triquetra cells. No effect on the motility of $H$. triquetra cells was observed when they were exposed to $C$. polylepis concentrations $<2 \times$ $10^{4}$ cells $\mathrm{ml}^{-1}$ (Fig. 3A-D). However, when the $C$. polylepis batch culture reached a cell concentration of

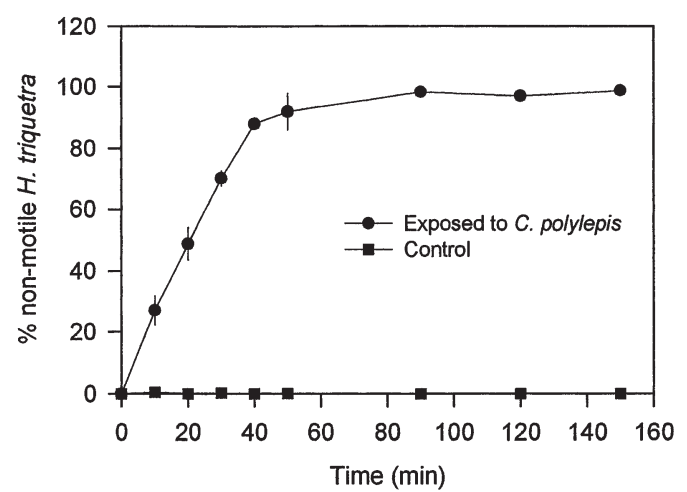

Fig. 1. Percentage of non-motile Heterocapsa triquetra cells found at the bottom of a multidish well as a function of time. (•) H. triquetra cells added to a Chrysochromulina polylepis culture $\left(1.5 \times 10^{5}\right.$ cells ml ${ }^{-1}$ at $\left.\mathrm{pH} 8.36\right)$; (घ) H. triquetra cells added to $\mathrm{f} / 2$-medium (Control). Data points refer to treatment means \pm 1 SE $(n=3)$ 

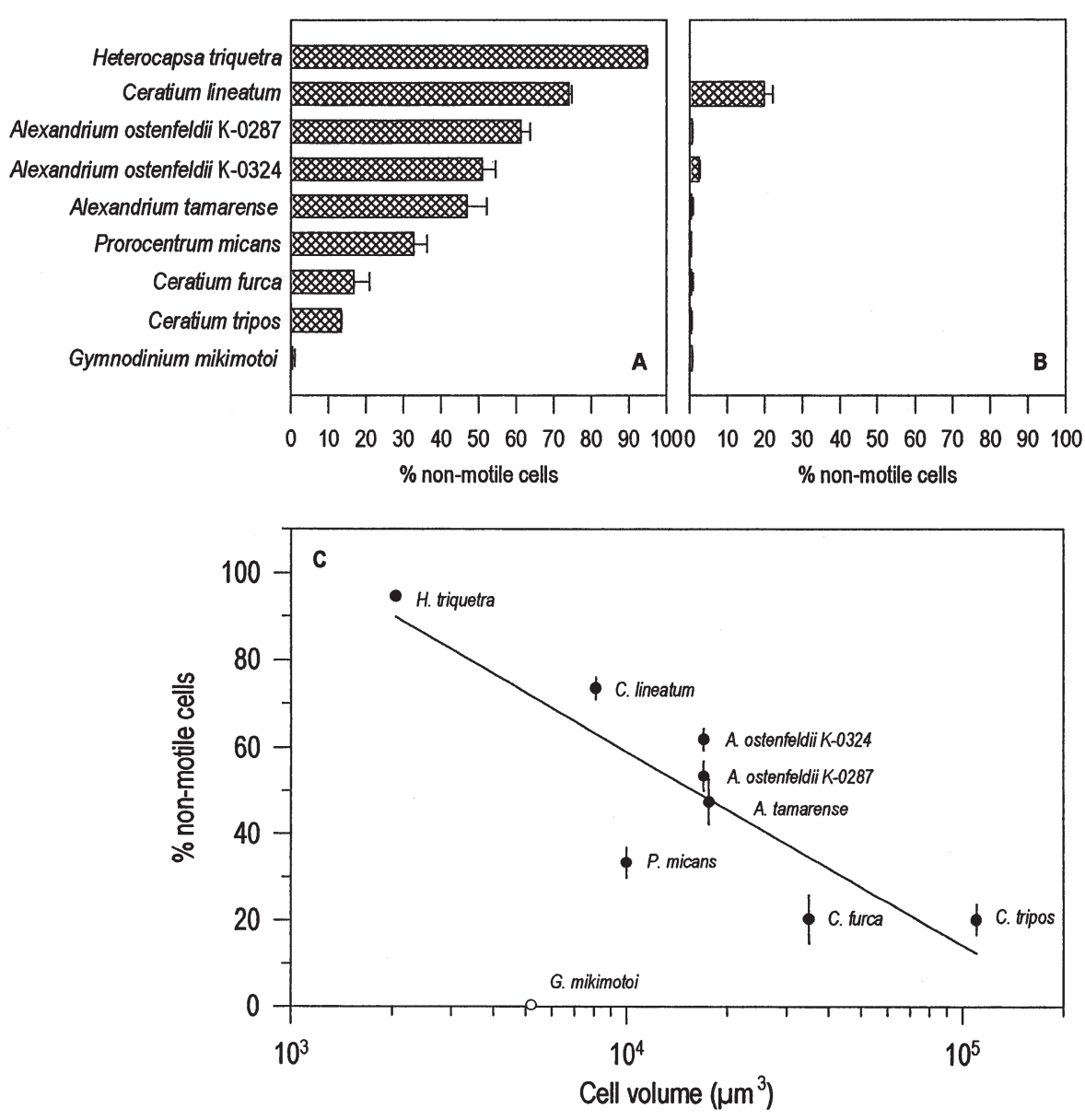

Fig. 2. (A) Percentage of non-motile dinoflagellates after $2 \mathrm{~h}$ of exposure to a Chrysochromulina polylepis suspension containing $1.9 \times 10^{5} \mathrm{cells} \mathrm{ml}^{-1}$, after correction for non-motile cells found in the control experiment, $\mathrm{pH}=8.8$. (B) Percentage non-motile cells in the control experiment, $\mathrm{pH}=8.8$. (C) Relationship between the cell volume of the tested algae and percentage of non-motile cells observed when exposed to a dense suspension of C. polylepis. Data points represent treatment means $\pm 1 \mathrm{SE}(\mathrm{n}=3)$. The solid line indicates a regression line. Only data points for those species affected were included in the regression (black dots). For details on the regression see Table 2

$4 \times 10^{4}$ cells $\mathrm{ml}^{-1}$, ca $50 \%$ of the $H$. triquetra population was immobilized (Fig. 3D). At higher cell concentrations of C. polylepis, the percentage of non-motile $H$. triquetra cells increased. Close to $100 \%$ of the $H$. triquetra population was immobilized at very high $C$. polylepis cell concentrations. Senescent cultures of C. polylepis did not immobilize $H$. triquetra cells (Fig. 3A,C).

$\mathrm{pH}$ was fairly constant until the Chrysochromulina polylepis culture reached a concentration of about $3.5 \times 10^{4}$ cells ml ${ }^{-1}$ (Fig. 3B). Above this cell concentration, the $\mathrm{pH}$ increased to about 8.8, as the culture reached stationary growth phase. The $\mathrm{pH}$ decreased to 7.9 in senescent cultures.

In a similar experiment, using the non-toxic Chrysochromulina simplex instead of C. polylepis, no immobilization of Heterocapsa triquetra cells was detected even at very high $C$. simplex concentrations (Fig. 3E, G,H). In this experiment, $\mathrm{pH}$ increased from 8.2 at the start of the experiment to about 9.2 when the culture had reached the stationary growth phase (Fig. 3F).

\section{Immobilization of Heterocapsa triquetra cells by Chrysochromulina polylepis: the effect of $\mathrm{pH}$}

Chrysochromulina polylepis cultures were grown to 3 different cell densities, after which the culture medium was adjusted to $\mathrm{pH}$ ranging from 6.6 to 9.9 (Fig. 4). The $\mathrm{pH}$ in these cultures was between 8.1 and 8.2 before adjustment. In all the cases, the $\mathrm{pH}$ had a dramatic effect on the percentage of Heterocapsa triquetra cells that had become non-motile after $2 \mathrm{~h}$ of exposure to

Table 2. Linear regression analysis $\left(\mathrm{p}\right.$ and $\mathrm{R}^{2}$ ) for the relationship between size and toxicity of Chrysochromulina polylepis to other plankton algae in the motility experiment and in the mixed cultures. Significant relationships are marked $\left(\mathrm{p}^{*}<0.05, \mathrm{p}^{* *}<0.01\right)$

\begin{tabular}{|c|c|c|c|}
\hline & $\mathrm{p}$ & $\mathrm{R}^{2}$ & Number of species and clones (n) \\
\hline \multicolumn{4}{|l|}{ Motility experiment } \\
\hline $\begin{array}{l}\text { All dinoflagellates except Prorocentrum minimum } \\
\text { and Gymnodinium mikimotoi }\end{array}$ & $0.0064^{* *}$ & 0.74 & 8 \\
\hline \multicolumn{4}{|l|}{ Growth experiments with mixed culture } \\
\hline All species and clones which were affected & 0.22 & 0.11 & 15 \\
\hline All species where a direct effect of pH could be ruled out & $0.042^{*}$ & 0.35 & 11 \\
\hline All dinoflagellates where a direct effect of $\mathrm{pH}$ could be ruled out & 0.18 & 0.24 & 6 \\
\hline
\end{tabular}



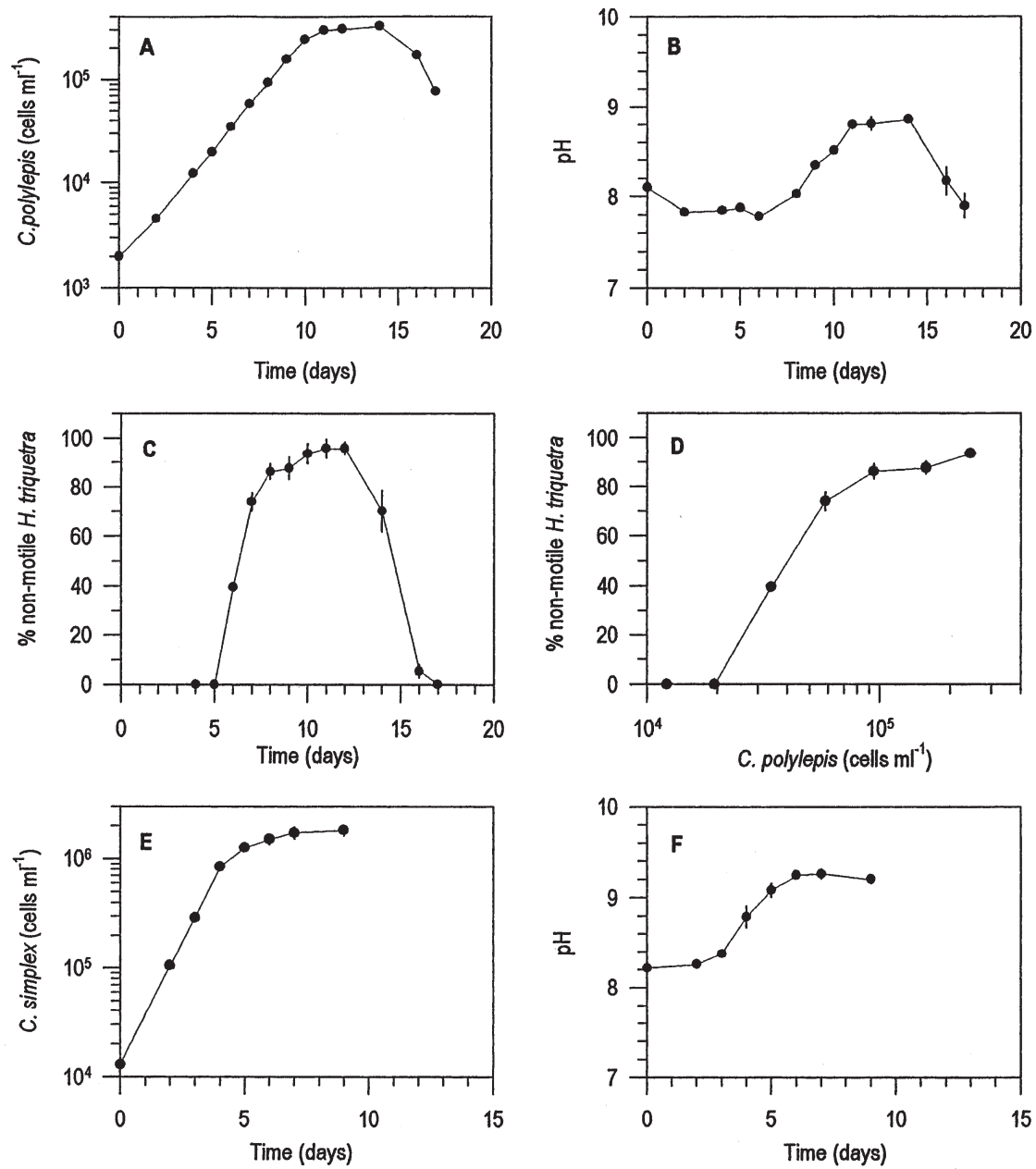

Fig. 3. Effect of Chrysochromulina polylepis on the motility of Heterocapsa triquetra and the control experiment with C. simplex. (A) Cell concentration of $C$. polylepis as a function of time in a batch culture. Exponential growth rate of $C$. polylepis $(\mu)=0.48 \pm$ 0.002 (mean $\pm 1 \mathrm{SE}, \mathrm{n}=3$ ). (B) $\mathrm{pH}$ in the $C$. polylepis culture as a function of time. (C) Percentage of non-motile $H$. triquetra cells as a function of time. (D) Percentage of non-motile $H$. triquetra cells as a function of cell concentration of C. polylepis in exponential growth phase. (E) Cell concentration of Chrysochromulina simplex as a function of time in batch culture. Exponential growth rate $(\mu)=1.03 \mathrm{~d}^{-1} \pm 0.069$ (mean $\pm 1 \mathrm{SE}, \mathrm{n}=3$ ). ( $\mathrm{F}) \mathrm{pH}$ in a C. simplex culture as a function of time. (G) Percentage of non-motile $H$. triquetra cells as a function of time. (H) Percentage of non-motile $H$. triquetra cells as a function of cell concentration of C. simplex in exponential growth phase. All data points refer to treatment means $\pm 1 \mathrm{SE}(\mathrm{n}=3)$

the C. polylepis culture. At the lowest C. polylepis concentration, the greatest percentage of non-motile $H$. triquetra cells was observed at a $\mathrm{pH}$ ranging from 8.9 to 9.6, while no effect on the motility of $H$. triquetra cells could be detected in a similar culture at $\mathrm{pH}<7.7$. At the highest $C$. polylepis concentration, the greatest percentage of non-motile $H$. triquetra cells was observed at $\mathrm{pH}>7.25$. Below this $\mathrm{pH}$, the percentage of non-motile $H$. triquetra cells decreased with decreasing $\mathrm{pH}$, and at pH 6.8 only motile cells were observed. An effect of $\mathrm{pH}$ itself on the swimming behaviour of $H$. triquetra could be detected at $\mathrm{pH}>9.5$ (Fig. 4).

\section{Interaction between Chrysochromulina polylepis and Heterocapsa triquetra in a mixed batch culture}

The interaction between of Chrysochromulina polylepis and Heterocapsa triquetra was studied in a mixed batch culture, which was initiated at low cell concentrations (Fig. 5). Non-motile Heterocapsa triquetra cells were first detected at a low percentage $(8 \%)$ in the mixed culture at Day 6, when the concentration of $C$. polylepis had reached ca $3 \times 10^{4}$ cells ml ${ }^{-1}$ (Fig. 5E,F). The following day, the percentage of non-motile $H$. triquetra cells had increased to $72 \%$, and the concentra- 


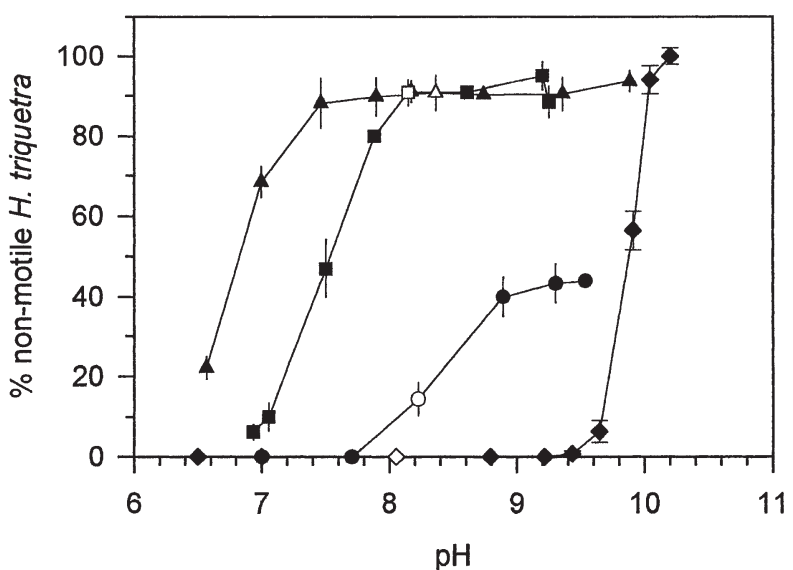

Fig. 4. Percentage of non-motile Heterocapsa triquetra cells as a function of $\mathrm{pH}$ in the growth medium of Chrysochromulina polylepis, using 3 different cell concentrations of $C$.

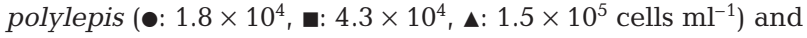
a control ( $\bullet$ ) using only growth medium. Open symbols refer to the initial values of $\mathrm{pH}$ in the individual experiments. Data points refer to treatment means $\pm 1 \mathrm{SE}(\mathrm{n}=3)$ tion of $C$. polylepis had reached $4.7 \times 10^{4}$ cells $\mathrm{ml}^{-1}$. From Day 10 to 16 , all $H$. triquetra cells in the mixed culture were non-motile. Between Days 16 and 18, all $H$. triquetra cells in the mixed culture became motile and only motile cells were observed in the mixed culture for the remaining study period (Fig. 5F).

Growth of Heterocapsa triquetra in the mixed culture was unaffected by the presence of Chrysochromulina polylepis until Day 6 (see Fig. 5A). The growth of the $H$. triquetra population stopped between Days 6 and 7 at a $H$. triquetra concentration of 200 cells ml ${ }^{-1}$, and a dramatic decrease in the $H$. triquetra population was observed from Day 7 to Day 16. From Day 16, the $H$. triquetra population increased from ca $1.4 \mathrm{cells} \mathrm{ml}^{-1}$ to 550 cells $\mathrm{ml}^{-1}$ at the end of the experiment. When $H$. triquetra was grown in monoculture, it reached a cell concentration of ca $4 \times 10^{4}$ cells ml ${ }^{-1}$ (Fig. 5C).

The growth response of Chrysochromulina polylepis in the mixed culture with Heterocapsa triquetra was quite similar to that obtained when C. polylepis was grown in monoculture, at least for the first $16 \mathrm{~d}$.
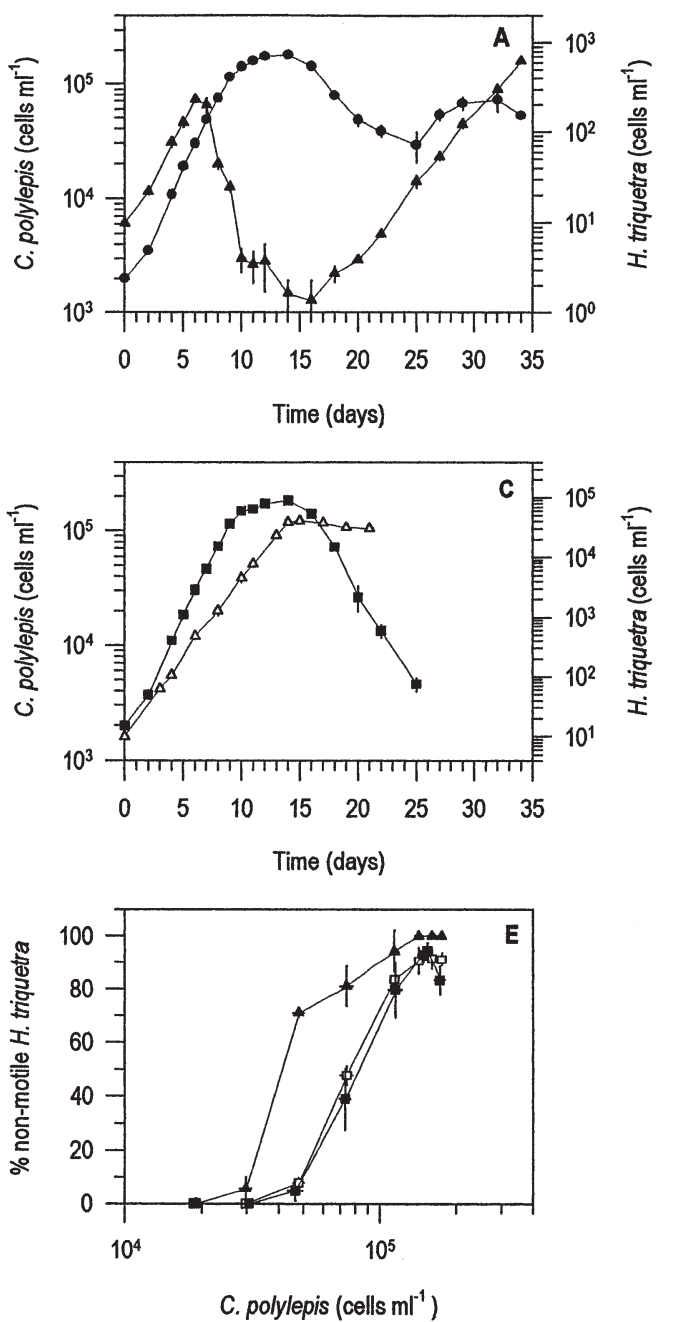

C. polylepis (cells $\mathrm{ml}^{-1}$ )
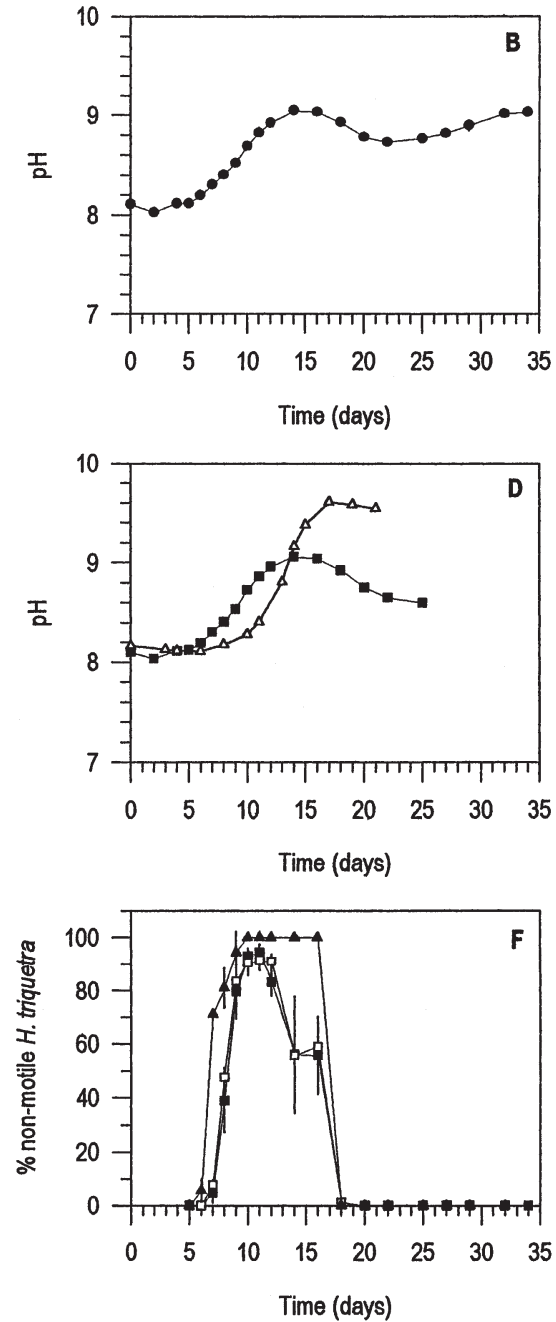

Fig. 5. Effect of Chrysochromulina polylepis on Heterocapsa triquetra in mixed batch cultures. (A) Cell concentrations of

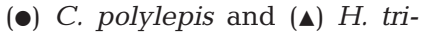
quetra. Exponential growth rate of C. polylepis $(\mu)=0.47 \mathrm{~d}^{-1} \pm$ 0.013 (mean $\pm 1 \mathrm{SE}, \mathrm{n}=3$ ) using data from Days 2 to 6. (B) $\mathrm{pH}$ in the mixed culture. (C) Cell concentrations of $(\square) C$. polylepis and $(\Delta) H$. triquetra in monocultures. Exponential growth rate of C. polylepis $(\mu)=0.48 \mathrm{~d}^{-1} \pm$ 0.08 (mean \pm 1 SE, $\mathrm{n}=3$ ) using data from Days 2 to 6. (D) $\mathrm{pH}$ in the monoculture of (घ) C. polylepis and $(\Delta) H$. triquetra. (E) Percentage of non-motile $H$. triquetra cells in the mixed culture as a function of $C$. polylepis concentration (only data from the first $12 \mathrm{~d}$ ). ( $\mathbf{\Delta}) H$. triquetra cells already in the mixed cultures, (घ) H. triquetra cells added to the mixed cultures and () H. triquetra cells added to monocultures of $C$. polylepis. (F) Percentage of non-motile $H$. triquetra cells as a function of incubation time (symbols the same as in E). Data points refer to treatment means \pm 1 SE $(n=3)$ 
However, if the culture was kept for a longer time, C. polylepis survived better in the mixed culture than in monoculture and to some extent even resumed growth (Fig. 5A,C). Thus, H. triquetra did not negatively affect $C$. polylepis in the mixed culture.

An increase in $\mathrm{pH}$, from about 8 at the beginning of the experiment to 9.05 at the early stationary growth phase of Chrysochromulina polylepis culture, was observed in both the monoculture and in the mixture culture with Heterocapsa triquetra. As the C. polylepis population became senescent, $\mathrm{pH}$ decreased to 8.6-8.7. A slight increase in $\mathrm{pH}$ to ca 9 was found in the mixed cultures at the end of the experiment (Fig. 5B).

It is noteworthy that Chrysochromulina polylepis which had been grown in monoculture had the same ability to immobilize Heterocapsa triquetra cells as C. polylepis grown in the mixed culture (Fig. 5E). It is also noteworthy that the percentage of $H$. triquetra cells which became non-motile after $2 \mathrm{~h}$ of exposure to the $C$. polylepis culture was always low compared to that observed for $H$. triquetra cells that had been growing together with $C$. polylepis in the mixed culture (Fig. 5E). This indicates that the effect of C. polylepis on the motility of $H$. triquetra is not always fully developed within the exposure time used $(2 \mathrm{~h})$.

A similar experiment as that described above was carried out using the Chrysochromulina simplex instead of C. polylepis (Fig. 6). C. simplex did affect the swimming behaviour of Heterocapsa triquetra (Fig. 6E,F). When the mixed culture went into stationary growth phase, pH increased to 9.2 (Fig. 6B).

\section{Effects of the initial concentration of Chrysochromulina polylepis on the growth response of Heterocapsa triquetra cells}

The effect of the initial concentration of Chrysochromulina polylepis on the growth response of Heterocapsa triquetra in mixed cultures was also studied
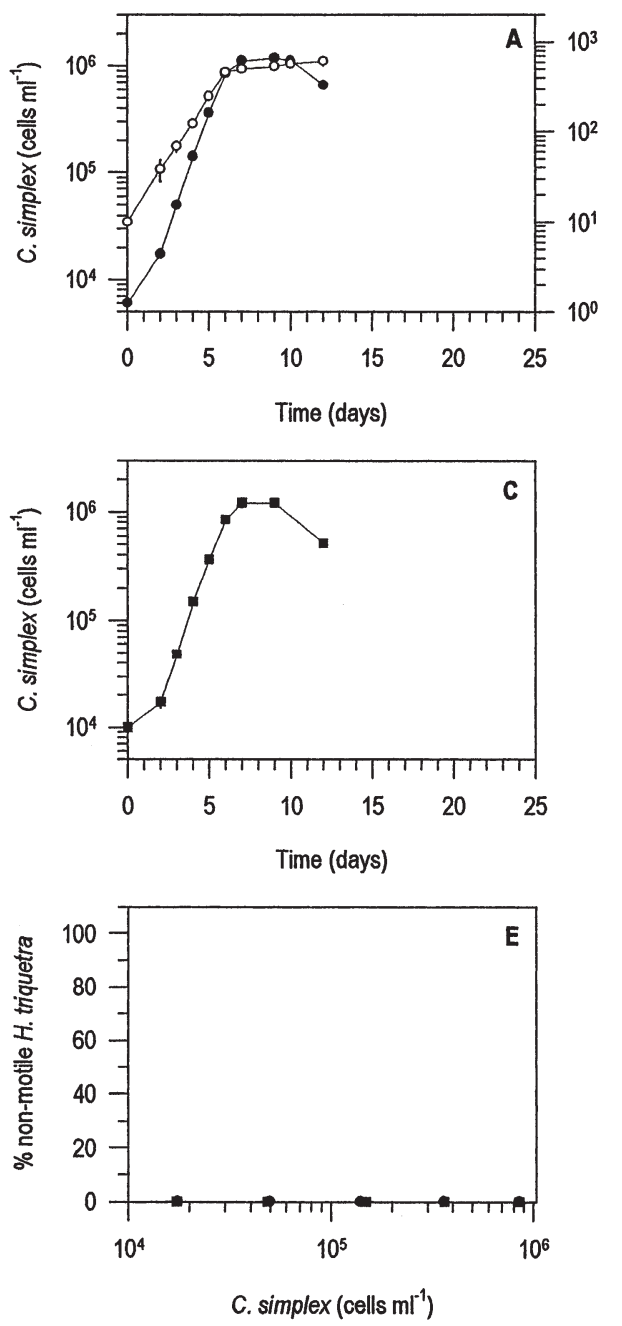
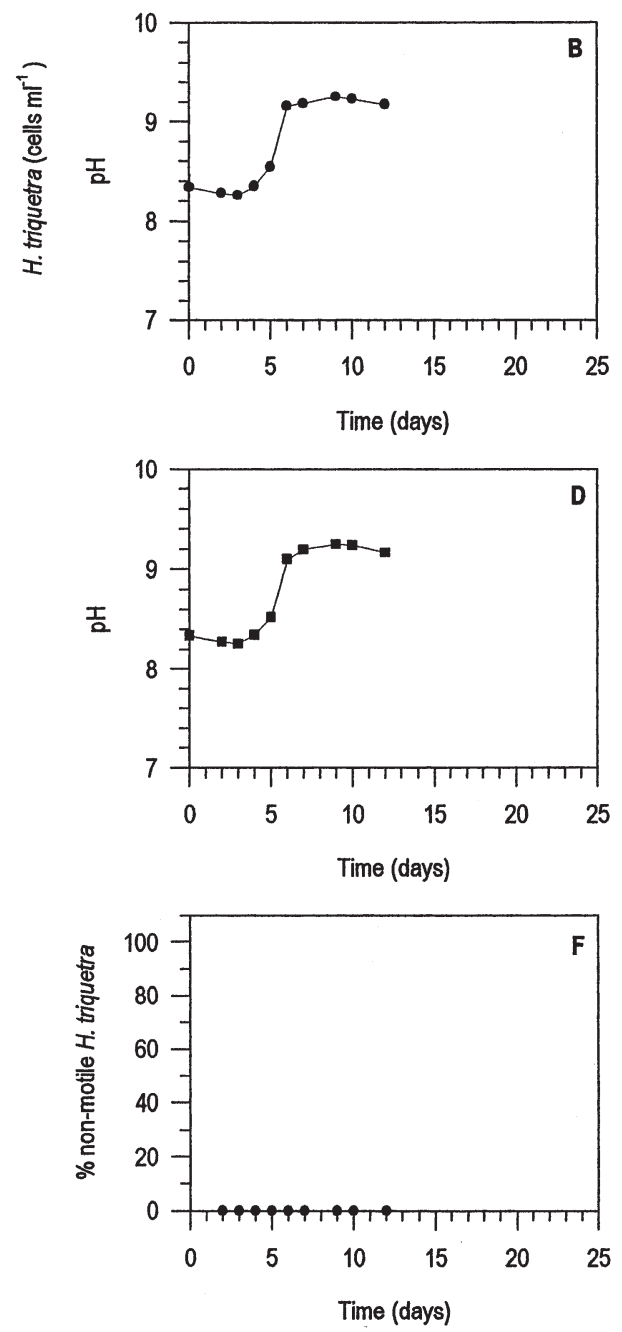

Fig. 6. Control experiments: the effect of Chrysochromulina simplex on Heterocapsa triquetra in a mixed batch culture. (A) Concentrations of (•) C. simplex and (o) H. triquetra in the mixed culture as a function of time. (B) $\mathrm{pH}$ in the mixed culture. (C) Concentration of C. simplex in the monoculture. (D) $\mathrm{pH}$ in the monoculture of C. simplex. (E) Percentage of non-motile $H$. triquetra cells in the mixed culture. (₫) H. triquetra cells already in the mixed culture, (घ) H. triquetra cells added to the mixed cultures, and (ם) $H$. triquetra cells added to monocultures of $C$. simplex. (F) Percentage of non-motile $H$. triquetra cells (symbols the same as in E). Data points refer to treatment means $\pm 1 \mathrm{SE}$ $(\mathrm{n}=3)$ 
(Fig. 7). The initial growth rate of $H$. triquetra in the 3 mixtures was the same as that obtained when $H$. triquetra was grown in monocultures (compare Fig. 5C with Fig. 7A-C). A decrease in the $H$. triquetra population was observed on Day 4 in the culture with the highest initial C. polylepis concentration (Fig. 7A). In the 2 cultures which were initiated at lower C. polylepis concentrations, the decrease in $H$. triquetra numbers appeared some days later (Days 6 and 7). Nevertheless, and irrespective of the initial concentration of $C$. polylepis, the decline in $H$. triquetra numbers always began when the $C$. polylepis concentration reached ca $3 \times 10^{4}$ cells $\mathrm{ml}^{-1}$. In all cases, $\mathrm{pH}$ increased from about 8 at the beginning of the experiment to 8.25, when the harmful effect was observed.

\section{Growth interactions between Chrysochromulina polylepis and algae belonging to different taxa}

Growth of 15 isolates (14 species) of algae in monoculture and in mixture with Chrysochromulina polylepis was also studied (Figs. 8 \& 9). All algae were in an exponential growth phase at the beginning of the experiment. After some time in the mixed cultures with C. polylepis, the growth rate of all algae, except Prorocentrum minimum, was reduced. While the growth of some algae had already been affected between Days 2 and 3, the growth of other algae was not affected until between Days 6 and 7. Growth reduction of the tested algae was soon followed by a decline in their population densities. The growth response of C. polylepis in monoculture and in all mixed cultures was identical, indicating that C. polylepis was not positively or negatively affected by the other algae within the study period (Figs. $8 \& 9$ ).
The negative effect of Chrysochromulina polylepis on the growth of the other algae was in most cases observed at a $\mathrm{pH}$ which did not affect these species when they were grown in monocultures. However, it cannot be excluded that the negative effect of C. polylepis on the growth of Ceratium furca, Ceratium tripos, Dictyocha speculum, and Gymnodinium mikimotoi was due to a harmful effect caused by the high $\mathrm{pH}$, rather than toxic substances released from C. polylepis.

For the algae in which a harmful effect of the high $\mathrm{pH}$ alone can be excluded, a reduction in growth rates of the algae was obtained at Chrysochromulina polylepis concentrations ranging from 1.1 to $5.19 \times 10^{4}$ cells $\mathrm{ml}^{-1}$ (Figs. $8 \& 9$, Tables $3 \& 4$ ). When the C. polylepis concentration required to induce a growth reduction was plotted against the cell size of all tested algae, no significant size relationship was found (Fig. 10, Table 2). However, omitting the 4 species in which a harmful effect of $\mathrm{pH}$ itself cannot be excluded, a significant relationship is found ( $p<0.05)$, although the correlation coefficient is not very high $\left(\mathrm{R}^{2}=0.35\right)$. No significant size relationship was found when only dinoflagellates were taken into consideration (Table 4).

\section{DISCUSSION}

In the present study, Chrysochromulina polylepis had a harmful effect on almost all the algae tested. Three stages of harmful response could be identified: an early response which concerned itself with flagellar beating (documented for the dinoflagellates), a secondary response which saw a reduction in population growth rate and a third response which included population death. The fact that the tested algae were immobilized after a short-time exposure to a dense $C$.
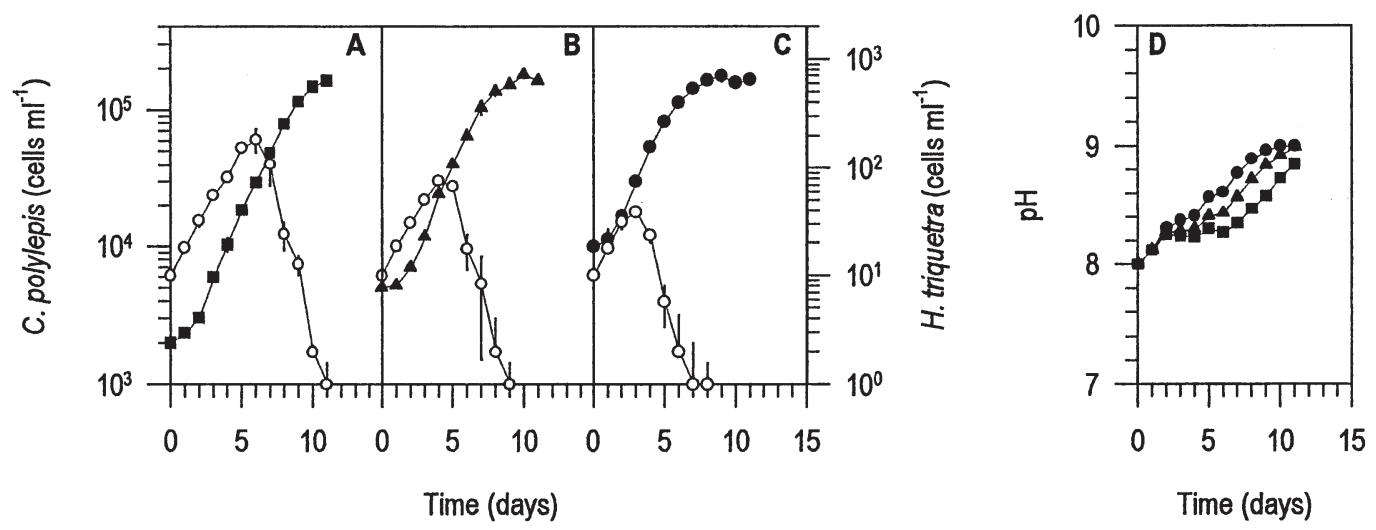

Fig. 7. Effect of the initial concentration of Chrysochromulina polylepis on the growth response of Heterocapsa triquetra in mixed batch cultures. (A-C) Concentrations of C. polylepis and $H$. triquetra with different initial concentrations of C. polylepis as a function of time. (o) Cell concentrations of $H$. triquetra, while filled symbols refer to the cell concentrations of $C$. polylepis. Initial

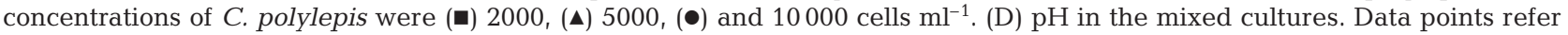
to treatment means $\pm 1 \mathrm{SE}(\mathrm{n}=3)$ 

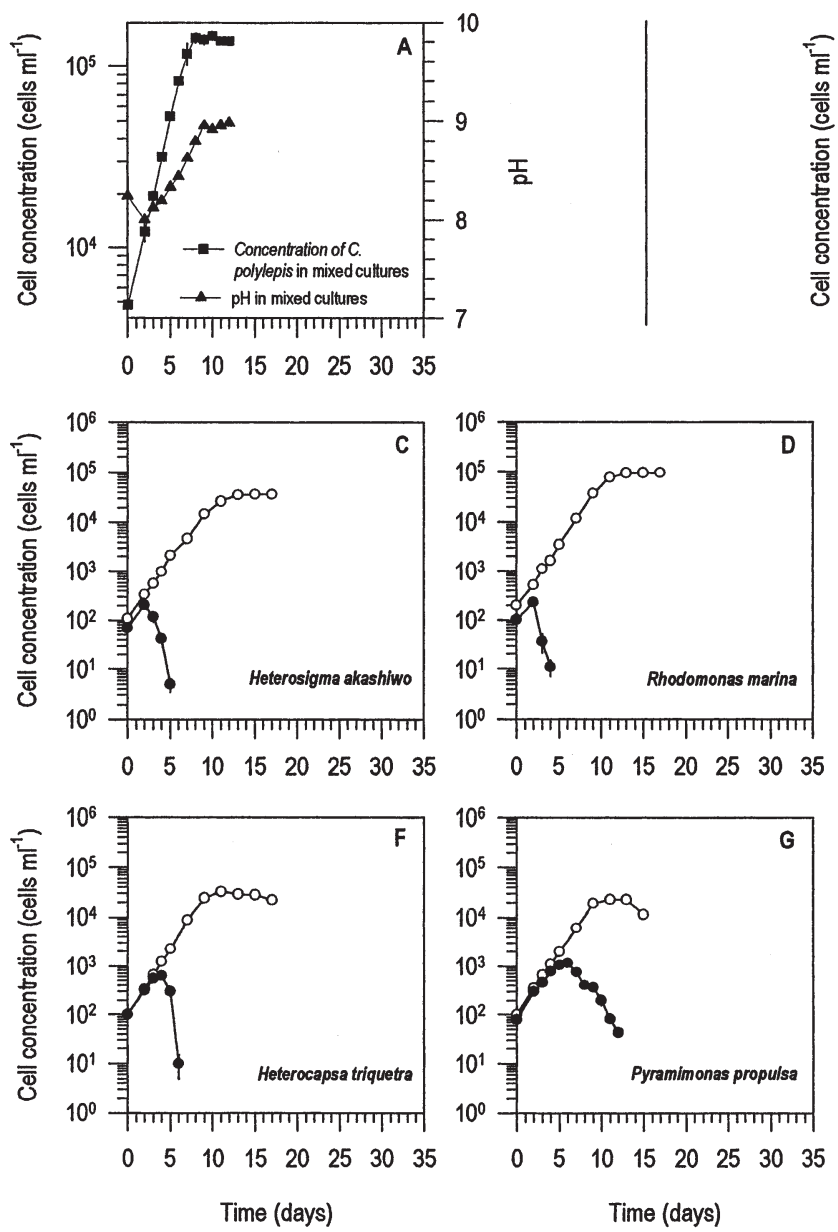

polylepis culture suggests that the harmful response could be due to toxins released from C. polylepis. However, in the mixed growth experiments potentially harmful effects due to high $\mathrm{pH}$ itself must be taken into account, because high $\mathrm{pH}$ can affect growth and survival of marine phytoplankton, when it exceeds 9 to 9.5 (Goldman et al. 1982a,b, Chen \& Durbin 1994), although some species can tolerate $\mathrm{pH}>9.5$ (Humphrey 1975, Goldman et al. 1981).

A harmful effect caused by high pH could in most cases be excluded in the mixed growth experiments. This is because the reduced growth rates of the tested algae were observed at a $\mathrm{pH}$ which did not affect the growth of these species when they were grown in monoculture (Tables $3 \& 4$ ). However, in the cases of Ceratium furca, Ceratium tripos, Dictyocha speculum, and Gymnodinium mikimotoi it was impossible to differentiate between the harmful effect caused by a high $\mathrm{pH}$ and that caused by toxins released from C. polylepis. The fact that $C$. furca and $C$. tripos were negatively affected in the motility tests suggests that they must have been at least partly affected by toxins released by C. polylepis. Interestingly, Gymnodinium
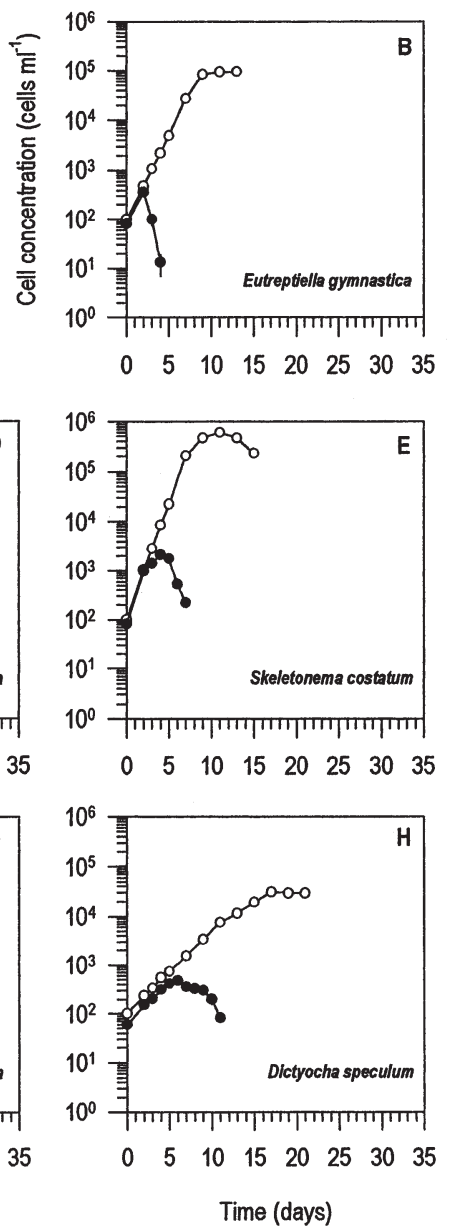

Fig. 8. Effect of Chrysochromulina polylepis on growth and survival of 7 algal species belonging to different taxa. (A) Average cell concentrations of C. polylepis in all the mixture experiments and $\mathrm{pH}$. Exponential growth rate of $C$. polylepis $(\mu)=0.47 \mathrm{~d}^{-1} \pm 0.03$ (mean $\pm 1 \mathrm{SE}, \mathrm{n}=21$ ) using data from Days 2 to 6 . (B-H) Average cell concentrations of individual algal species (o) in monocultures and $(\bullet)$ in mixed cultures with $C$. polylepis. Data points represent treatment means \pm 1 SE $(n=3)$

mikimotoi was not affected in the motility test, suggesting that it was mainly affected by the high $\mathrm{pH}$ in the mixture experiment and not by toxins released by C. polylepis.

\section{Toxic effect of Chrysochromulina polylepis:} dependence of cell concentration and growth phase

The experiments on the ability of Chrysochromulina polylepis to immobilize the dinoflagellate Heterocapsa triquetra clearly demonstrated how both the concentration and the growth phase of the C. polylepis culture affected its toxicity to another alga. C. polylepis cultures were not toxic to $H$. triquetra at $C$. polylepis concentrations below 2 to $3 \times 10^{4}$ cells ml $^{-1}$ (Figs. 3D \& 5E). Above this cell concentration, the toxic effect of $C$. polylepis cultures increased with cell density. However, senescent cultures of $C$. polylepis were non-toxic (Figs. 3D \& 5E).

Several studies dealing with the effects of nutrient limitation on toxin content (as measured by a haemolytic test) of Chrysochromulina polylepis and another 

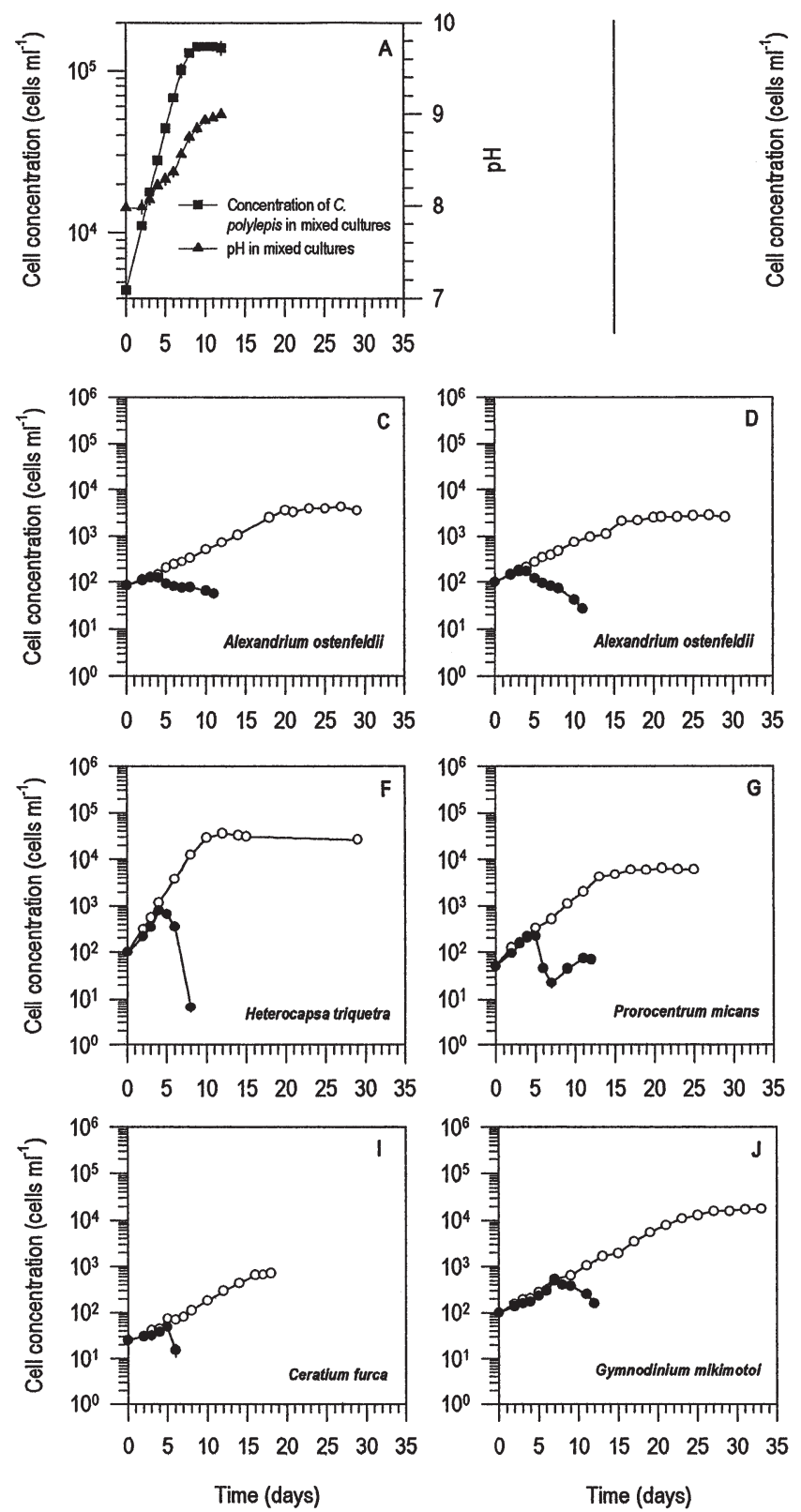

prymnesiophyte Prymnesium parvum indicate that P limitation increases the cellular toxin content (Shilo 1967, 1971, Edvardsen \& Paasche 1992, Meldahl et al. 1994, Johansson \& Granéli 1999a,b). Recently, Johansson \& Granéli (1999b) demonstrated that N limitation also leads to an increase in cellular toxin content in C. polylepis. This raises a question about the nutrient status of the senescent C. polylepis cultures in our experiments.

We used the f/2-medium algal growth medium (Guillard 1983) in which nitrogen and phosphorus are added in very high concentrations to the medium (Table 5). A simple calculation using the maximum cell concentration of Chrysochromulina polylepis and its
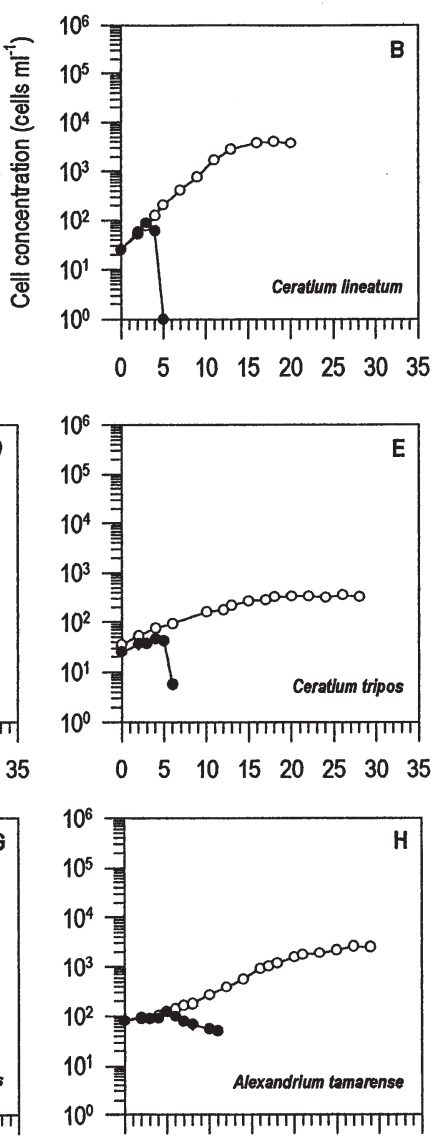

$\begin{array}{llllllll}0 & 5 & 10 & 15 & 20 & 25 & 30 & 35\end{array}$

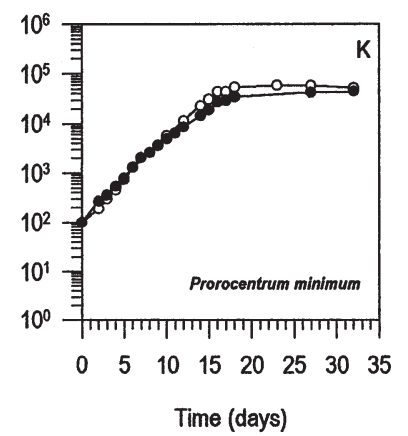

Fig. 9. Effect of Chrysochromulina polylepis on the growth and survival of 10 species of dinoflagellates. (A) Average cell concentration of C. polylepis in all the mixture experiments and $\mathrm{pH}$. Exponential growth rate of $C$. polylepis $(\mu)=0.45 \mathrm{~d}^{-1} \pm 0.05$ (mean $\pm 1 \mathrm{SE}, \mathrm{n}=30$ ) using data from Days 2 to 6. (B-I) Average cell concentrations of individual algal species (o) in monocultures and (•) in mixed cultures with C. polylepis. Data points represent treatment means $\pm 1 \mathrm{SE}(\mathrm{n}=3)$

cellular carbon content resulted in an estimated uptake of nitrogen and phosphorus by the cells of only about 11 and $16 \%$ of the nitrogen and phosphorus available, respectively (Table 5). Considering that the negative effect of $C$. polylepis was achieved at a cell concentration of about 10 times less than the maximum cell concentration, only about 1.1 to $1.6 \%$ of the available $\mathrm{N}$ and $\mathrm{P}$ in the medium was incorporated into cells at the time when the toxic effect first occurred in the mixed cultures. Thus, C. polylepis was neither N nor P limited in the present study.

So what actually did limit the growth of the Chrysochromulina polylepis cultures in the stationary growth phase in our study and why did this lead to non-toxic 
Table 3. List of algae used in the experiments on growth interactions between Chrysochromulina polylepis and algae belonging to different taxa, including data on cell concentration of $C$. polylepis when the harmful effect occurred, and the $\mathrm{pH}$ in the culture medium under different conditions. See text for further details

\begin{tabular}{|c|c|c|c|c|}
\hline Algal taxa & $\begin{array}{c}\text { Concentration }\left(\times 10^{3} \text { cells } \mathrm{ml}^{-1}\right) \\
\text { of } C \text {. polylepis when } \\
\text { harmful effect occurred } \\
(\text { mean } \pm \mathrm{SD})\end{array}$ & $\begin{array}{l}\mathrm{pH} \text { in mixed } \\
\text { culture when } \\
\text { harmful effect } \\
\text { occurred }\end{array}$ & $\begin{array}{c}\text { pH in } \\
\text { monoculture when } \\
\text { exponential } \\
\text { growth was affected* }\end{array}$ & $\begin{array}{c}\mathrm{pH} \text { in } \\
\text { monoculture } \\
\text { in stationary } \\
\text { growth phase* }\end{array}$ \\
\hline \multicolumn{5}{|l|}{ Bacillariophyceae } \\
\hline Skeletonema costatum (Grev.) Cleve & $12.9 \pm 2.06$ & 8.00 & 8.49 & 9.21 \\
\hline \multicolumn{5}{|l|}{ Cryptophyceae } \\
\hline $\begin{array}{l}\text { Rhodomonas marina (PA Dang.) Lemmerm. } \\
\text { Dictyochophyceae }\end{array}$ & $13.1 \pm 1.45$ & 8.00 & 8.74 & 9.93 \\
\hline Dictyocha speculum Ehrenb. & $55.0 \pm 2.01$ & 8.34 & 8.30 & 8.81 \\
\hline \multicolumn{5}{|l|}{ Dinophyceae } \\
\hline $\begin{array}{l}\text { Heterocapsa triquetra Ehrenb. } \\
\text { Euglenophyceae }\end{array}$ & \multicolumn{3}{|c|}{ Euglenophyceae } & 9.43 \\
\hline Eutreptiella gymnastica Throndsen & $10.9 \pm 0.55$ & 8.00 & 9.00 & 9.22 \\
\hline \multicolumn{5}{|l|}{ Prasinophyceae } \\
\hline $\begin{array}{l}\text { Pyramimonas propulsa Moestrup et DRA Hill } \\
\text { Raphidophyceae }\end{array}$ & $30.4 \pm 2.76$ & 8.22 & 8.55 & 8.80 \\
\hline Heterosigma akashiwo (Hada) Hada & $11.6 \pm 1.40$ & 8.00 & 8.52 & 9.15 \\
\hline
\end{tabular}

Table 4. List of dinoflagellates used in the mixed growth experiments with Chrysochromulina polylepis, including data on the cell concentration of C. polylepis when the harmful effect occurred, and $\mathrm{pH}$ in the culture medium under different conditions. See text for further details

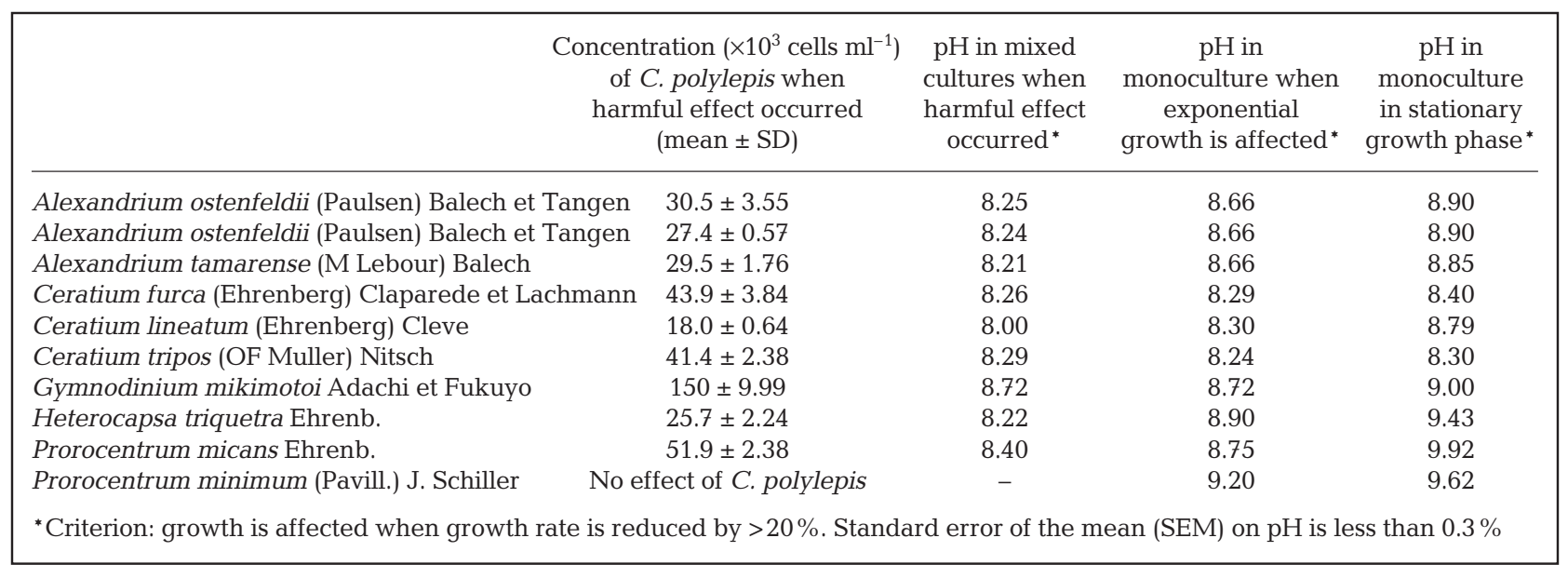

cultures? One possible explanation could be that $\mathrm{pH}$ limited the growth of C. polylepis in stationary cultures and that this lead to non-toxic cultures. Another possible explanation could be inorganic carbon limitation. The toxins described for $C$. polylepis contain high amounts of carbon. Thus, a possible explanation for the loss of toxicity during the stationary growth phase in our experiments could be carbon limitation. The content of dissolved inorganic carbon (DIC) in the $f / 2$ growth medium was on average $1.7 \mathrm{mM}$ (P.J.H. unpubl. results). Again, a simple calculation using the maximum cell concentration of $C$. polylepis and its cellular carbon content results in an estimated uptake of carbon by the cells of only about $35 \%$ of the available amount of DIC (Table 5). However, when pH increased from 8 to 9 , the concentration of inorganic carbon available as $\mathrm{CO}_{2}$ decreased. Thus, if $C$. polylepis does not utilize bicarbonate very well at high $\mathrm{pH}$, cultures may possibly become $\mathrm{CO}_{2}$ limited. Future studies are required to test whether this is true or not.

It was interesting to observe that a Chrysochromulina polylepis culture, which had lost its toxicity in the stationary growth phase, did not regain its toxicity when positive growth was resumed, even though the cell concentration was considerably above a concentration which is usually toxic (Fig. 5A). This indicates 


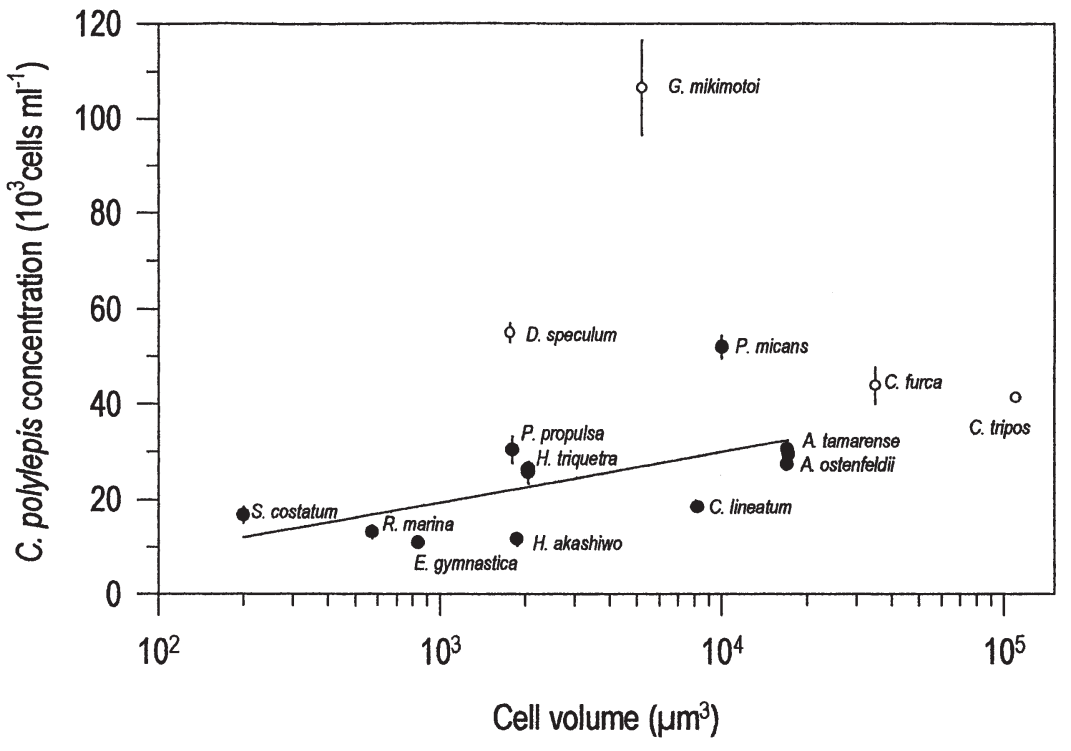

Fig. 10. Relationship between the cell volume of tested algae and the concentration of Chrysochromulina polylepis required to suppress their growth rate by $>20 \%$. (o) Those cases in which a direct effect of pH cannot be excluded. Solid line indicates regression line based on data where a direct effect of $\mathrm{pH}$ can be excluded. See text for further explanation

\section{Effect of pH on the toxicity of Chrysochromulina polylepis}

The role $\mathrm{pH}$ played in the toxicity of Chrysochromulina polylepis to Heterocapsa triquetra cells was studied at 3 different C. polylepis concentrations using the motility test. In all cases, the highest toxicity of the $C$. polylepis cultures was observed in alkaline medium with a $\mathrm{pH}$ between 8 and 9 (Fig. 4).

Studies on the interaction between potentially toxic algae and other organisms rarely take the role $\mathrm{pH}$ plays in the toxicity into account. Exceptions are the studies by Ulitzur \& Shilo (1964, 1966), who observed a similar effect of $\mathrm{pH}$ on the toxicity of the prymnesiophyte Prymnesium parvum to fish. They found that a change from $\mathrm{pH} 8$ to 9 increased the toxicity by a factor of 4 . At a $\mathrm{pH}$ of 7, no toxic effect to fish could be detected. Likewise, Proctor (1957) demonstrated that the toxic effect of the chlorophyte Chlamydomonas reinhardi to another chlorophyte Haematococcus pluvialis was highest at high $\mathrm{pH}$, and the allelopathic effect disappeared when changing the $\mathrm{pH}$ in a cell-free medium of C. reinhardi from 10 to 7.5. Proctor suggested that the toxic effect was due to fatty acids and could demonstrate that the toxicity of palmin and oil acid to $H$. pluvialis was highest at alkaline $\mathrm{pH}$.

In conclusion, pH may alter the toxicity of toxins produced by prymnesiophytes and other planktonic algae, and this should be considered when investigating the effect of toxic algae on other organisms. To what extent pH affected the toxicity of Chrysochromulina polylepis during the bloom in 1988 is uncertain, because data on $\mathrm{pH}$ from that period are completely lacking.

How $\mathrm{pH}$ affects the toxicity of algal toxins to other organisms is not well documented. Transformation into other derivatives of the toxin complex with a different degree of toxicity has been documented for the PSPtoxin complex (e.g. Boyer et al. 1986). Another possibility could be that release or breakdown of toxins in the medium is $\mathrm{pH}$ dependent (Simonsen \& Moestrup 1997). This topic needs to be addressed further.

\section{Is the toxic effect of Chrysochromulina polylepis on other algae dependent on their cell size?}

Among the algae that were sensitive to the toxins of Chrysochromulina polylepis, a positive relationship was found between the cell concentrations of C. polylepis needed for a reduction in growth rate of the 
exposed algae and their size (see Table 4 and Fig. 10). This could indicate that small cells are more sensitive than larger cells. However, the result should be interpreted with great caution. The reason is that these data were derived from the mixed culture experiments in which C. polylepis grew with a doubling time of ca $1.4 \mathrm{~d}$. Thus, a comparison of data in such an experiment is only valid if the 'response time' to the toxic substance is similar among the tested species. This was probably not the case, because a significant negative relationship was found between the size of the exposed dinoflagellates and the percentage of cells found nonmotile after $2 \mathrm{~h}$ of exposure to C. polylepis (Fig. 2, Table 2). This motility experiment was carried out at a very high concentration of $C$. polylepis $\left(1.9 \times 10^{5}\right.$ cells $\mathrm{ml}^{-1}$ ), which in the mixture experiments was lethal to all the algae that were affected (Figs. 8 \& 9). Thus, it may well be that what we first interpreted as a higher sensitivity of small algae to C. polylepis, may in fact be a size-dependent response time to the toxins instead.

\section{Why do toxins released from Chrysochromulina polylepis not affect some algal species?}

Yasumoto et al. (1990) demonstrated hemolytic effects of cell-free extracts from Chrysochromulina polylepis and Gymnodinium mikimotoi (= Gyrodinium aureolum). Chromatographic and mass spectrometric data indicate that these 2 algae produce toxic fatty acids (1-cyl-3-digalactogycerol and oktadecapentaen acid). Thus, the fact that $C$. polylepis and G. mikimotoi may produce the same toxins could be a likely reason why the toxins released by $C$. polylepis did not affect G. mikimotoi. Prorocentrum minimum has been connected to several toxic incidents in the past (Nakazima 1968, Tangen 1980). However, the toxins identified so far from $P$. minimum are structurally different from those of C. polylepis and display other symptoms (Trick et al. 1981, Grzebyk et al 1997). It is interesting that a study by Windust et al. (1996) on the effects of the DSP toxins okadaic acid and dinophysistoxin-1 on a variety of algae, found that these toxins, even at high doses, did not affect $P$. minimum. This may indicate that $P$. minimum may be more resistant to a variety of algal toxins; however, this needs to be studied in further detail.

\section{Conclusion}

Our results demonstrate that Chrysochromulina polylepis is toxic to a large variety of other planktonic algae at cell concentrations similar to those found during blooms in nature (e.g. Kaas et al. 1991, Edvard- sen \& Paasche 1998). Thus, the release of toxins by C. polylepis to the surrounding water may indeed explain why a bloom like the one in 1988 in Scandinavian waters became essentially monospecific at high cell concentrations. However, our results also demonstrate that factors such as $\mathrm{pH}$ and perhaps $\mathrm{CO}_{2}$ limitation affect the toxicity of $C$. polylepis to other planktonic algae.

Acknowledgements. We thank Alf Skovgaard and 2 anonymous reviewers for their constructive criticism and suggestions. The work was funded by both the Danish Natural Research Council project no. 9801391 and the European Commission (Research Directorate General-Environment Programme-Marine Ecosystems) through the BIOHAB project 'Biological control of Harmful Algal Blooms in European coastal waters: role of eutrophication' (contract EVK3-CT9900015). The BIOHAB project is part of the EC IMPACT cluster.

\section{LITERATURE CITED}

Boyer GL, Sullivan JJ, Andersen RJ, Taylor FJR, Harrison PJ, Cembella AD (1986) Use of high-performance liquid chromatography to investigate the production of paralytic shellfish toxins by Protogonyaulax spp. Mar Biol 93:361-369

Chen CY, Durbin EG (1994) Effects of pH on the growth and carbon uptake of marine phytoplankton. Mar Ecol Prog Ser 100:83-94

Dahl E, Lindahl O, Paasche E, Throndsen J (1989) The Chrysochromulina polylepis bloom in the Scandinavian waters during spring 1988. In: Cosper EM, Bricelj M, Carpenter EJ (eds) Novel phytoplankton blooms: causes and impacts of recurrent brown tides and other unusual blooms. Springer, Berlin, p 383-405

Edvardsen B, Paasche E (1992) Two motile stages of Chrysochromulina polylepis (Prymnesiophyceae): morphology, growth and toxicity. J Phycol 28:104-114

Edvardsen B, Paasche E (1998) Bloom dynamics and physiology of Prymnesium and Chrysochromulina. In: Anderson DM, Cembella AD, Hallegraeff GM (eds) Physiological ecology of harmful algal blooms. Springer, Berlin, p 193-208

Goldman JC, Dennett MR, Riley CB (1981) Test for allelopathic interactions between two marine microalgal species grown in intensive cultures. Curr Microbiol 6:275-279

Goldman JC, Azov Y, Riley CB, Dennett MR (1982a) The effect of $\mathrm{pH}$ in intensive microalgal cultures. I. Biomass regulation. J Exp Mar Biol Ecol 57:1-13

Goldman JC, Riley CB, Dennett MR (1982b) The effect of pH in intensive microalgal cultures. II. Species competition. J Exp Mar Biol Ecol 57:15-24

Granéli E, Paasche E, Maestrini SY (1993) Three years after the Chrysochromulina polylepis bloom in the Scandinavian waters in 1988: some conclusions of recent research and monitoring. In: Smayda TJ, Shimizu Y (eds) Toxic phytoplankton blooms in the sea. Elsevier, Amsterdam, p 25-32

Grzebyk D, Denardou A, Berland B, Pouchus YF (1997) Evidence of a new toxin in the red-tide dinoflagellate Prorocentrum minimum. J Plankton Res 19:1111-1124

Guillard RRL (1983) Culture of phytoplankton for feeding invertebrate animals. In: Berg CJ (ed) Culture of marine invertebrates. Hutchinson Ross Publishing $\mathrm{Co}$, Stroudsberg, PA, p 108-132 
Humphrey GF (1975) The photosynthesis: respiration ratio of some unicellular marine algae. J Exp Mar Biol Ecol 18: 111-119

Johansson N, Granéli E (1999a) Influence of different nutrient conditions on cell density, chemical composition, and toxicity of Prymnesium parvum (Haptophyta) in semi-continuous cultures. J Exp Mar Biol Ecol 239:243-258

Johansson N, Granéli E (1999b) Cell density, chemical composition and toxicity of Chrysochromulina polylepis (Haptophyta) in relation to different N:P supply ratios. Mar Biol 135:209-217

Kaas H, Larsen J, Møhlenberg F, Richardson K (1991) The Chrysochromulina polylepis bloom in the Kattegat (Scandinavia) May-June 1988. Distribution, primary production and nutrient dynamics in the late stage of the bloom. Mar Ecol Prog Ser 79:151-161

Maestrini SY, Granéli E (1991) Environmental conditions and ecophysiological mechanisms which led to the 1988 Chrysochromulina polylepis bloom: an hypothesis. Oceanol Acta 14:397-413

Meldahl AS, Edvardsen B, Fonnum F (1994) Toxicity of four potentially ichthyotoxic marine phytoflagellates determined by four different test methods. J Toxicol Environ Health 42:289-301

Myklestad MM, Ramlo B, Hestmann S (1995) Demonstration of strong interaction between the flagellate Chrysochromulina polylepis (Prymnesiophyceae) and a marine diatom. In: Lassus P, Arzul G, Erard E, Gentien P, Marcaillou C (eds) Harmful marine algal blooms. Lavoisier, Intercept Ltd, Hampshire, p 633-638

Nakazima M (1968) Studies on the source of shellfish poison in Lake Hamana. IV. Identification and collection of the noxious dinoflagellates. Bull Jpn Soc Sci Fish 34:130-132

Nielsen TG, Kiørboe T, Bjørnsen PK (1990) Effects of a Chrysochromulina polylepis subsurface bloom on the planktonic community. Mar Ecol Prog Ser 62:21-35

Proctor VW (1957) Studies of algal antibiosis using Haematococcus and Chlamydomonas. Limnol Oceanogr 2:125-139

Editorial responsibility: Otto Kinne (Editor),

Oldendorf/Luhe, Germany
Shilo M (1967) Formation and mode of action of algal toxins Bacteriol Rev 31:180-193

Shilo M (1971) Toxins of Chrysophyceae. In: Kadis S, Ciegler A, Ajl SJ (eds) Microbial toxins. Algal and fungal toxins, Vol 7. Academic Press, New York, p 67-103

Simonsen S, Moestrup Ø (1997) Toxicity tests in eight species of Chrysochromulina (Haptophyta). Can J Bot 75: 129-136

Strathmann RR (1967) Estimating the organic carbon content of phytoplankton from cell volume or plasma volume. Limnol Oceanogr 12:411-418

Tangen K (1980) Brunt vann i Oslofjorden i September 1979, forårsaget av den toksiske Prorocentrum minimum og andre dinoflagellater. Blyttia 38:145-158

Thomsen HA, Buck KR, Chavez FP (1994) Haptophytes as a components of marine phytoplankton. In: Green JC, Leadbeater BSC (eds) The haptophyte algae. Syst Assoc Spec Vol 51, Oxford University Press, New York, p 187-208

Tobisen A (1991) Growth rates of Heterophrys marina (Heliozoa) on Chrysochromulina polylepis. Ophelia 33:205-212

Trick CG, Harrison PJ, Andersen RJ (1981) Extracellular secondary metabolite production by the marine dinoflagellate Prorocentrum minimum in culture. Can J Fish Aquat Sci 38:864-867

Ulitzur S, Shilo M (1964) A sensitive assay system for determination of the ichthyotoxicity of Prymnesium parvum. J Gen Microbiol 36:161-169

Ulitzur S, Shilo M (1966) Mode of action of Prymnesium parvum Ichthyotoxin. J Protozool 13(2):332-336

Windust AJ, Wright JLC, McLachlan JL (1996) The effects of diarrhetic poisoning toxins, okadeic acid and dinophysistoxin-1, on the growth of microalgae. Mar Biol 126:19-25

Yasumoto T, Underdahl B, Aune T, Hormazabal V, Skulberg OM, Oshima Y (1990) Screening for haemolytic and ichthyotoxic components of Chrysochromulina polylepis and Gyrodinium aureolum from Norwegian coastal waters. In: Granéli E, Sundstrøm B, Edler L, Anderson DM (eds) Toxic marine phytoplankton. Elsevier, Amsterdam, p 436-440

Submitted: March 2, 2000; Accepted: October 17, 2000 Proofs received from author(s): June 1, 2001 